\title{
Pengampunan Yusuf ditinjau dari perspektif Teori Kognitif
}

\author{
Elia Dede Kurniawan, Hasniati H., Ester Aren Ibau
}

\begin{abstract}
Abstrak
Penulisan karya tulis ini bertujuan untuk menjelaskan Teori Kognitif atau teori belajar dalam memahami persoalan yang menyangkut kemampuan dan rasional akal, yang dipadukan dengan Nast Alkitab tentang pengampunan yang dilakukan Yusuf terhadap saudara-saudaranya, yang dapat dipahami dan dapat diterapkan dalam kehiudupan sehari-hari. Adapun latar belakang penulisan ini adalah,, Teori kognitif adalah kemampuan seseorang dalam mengembangkan kemampuan rasional atau akal. Penekanan teori ini adalah bagaimana proses kemampuan akal yang dimiliki orang lain, dalam memahami apa yang disampaikan dan dapat di repons ke dirinya dalam kehidupan sehari-hari. Penelitian yang kami lihat dengan pengamatan kami dalam kelas, bagaimana teori yang kami gunakan kami hubungkan dengan nats alkitab yang kami sampaikan dengan metode ceramah, diskusi, dan Tanya jawab. Dan dari hasil pengamatan kami menunjukan bahwa teori ini dapat megembangkan kepribadian masiswa dalam bertingkah laku dalam kehidupan sehari-hari dan teori ini sangat bermanfaat jika digunakan dalam kelas mengajar.
\end{abstract}

Kata-kata kunci: teori kognitif, Yusuf, pengampunan, pengalaman, belajar

\section{Pendahuluan}

Penulis memilih judul karena dirasa unik sebuah teori kognitif yang dapat dipadukan dengan kisah Alkitab. Dikarnakan selama ini pemahaman orang memahami kognitif hanya sebuah teori belajar biasa saja dan hanya sebuah teori dalam pisikologi, tetapi dari urutan teori ini dapat dipadukan dengan narasi Alkitab atau pelajaran Alkitab yang menimbulkan sebuah pemahaman baru dan terpadu bukan hanya sekedar menerapkan sebuah teori biasa dari kognitif tapi juga ada penerapan dari pembelajaran Alkitab. Dimulai dari sebuah pertayaan yang merujuk dari teks Alkitab atau narasi tertentu, yang tujuannya membawa orang berfikir dan mengembangkannya sehingga menimbulkan pernyataan-pernyataan yang baru. Dari penryataan ini muncul sebuah pehaman baru. Penulis memilih Tokoh Yusuf dalam memadukan teori ini, karena penulis melihat tentang apa yang dilakukan saudara-saudara Yusuf terhadap dirinya, yaitu memiliki perasaan iri terhadap Yusuf, membuang Yusuf kedalam sumur, memPerbuatan mereka yang kalau difikirkan secara manusiawipenulis ingin memberikan sebuah gambaran yang berkaitan dengan kehidupan kita hari ini. 


\section{Kajian Teori}

Teori perkembagan kognitif Jeans Piaget, para ahli berpendapat pembelajaran merupakan suatu proses aktif yang berlansung sementara anak berintraksi dengan lingkugannya. Teori pieget dikenal dengan teori yang menyatakan bahwa dalam pembelajaran terdapat proses, tujuan dan harapan seseorang merupakan sumber motivasi yang dapat membentuk ketidakselarasan", "1 mereka berusaha memikirkan informasi yang bermacam-macam dan mendapat pemahaman yang bukan didapat dari latihan atau hafalan". ${ }^{2}$

Teori ini mempuyai tingkatan yang dimulai dari tingkatan intelektual yang berhubungan dengan kedewasaan seseorang yaitu perkembangan sistem saraf otak. Penalaran moral, interaksi lingkugan fisik pengalaman fisik meningkatkan perkembagan timbulnya sebuah pemikiran yang kompeleks. Transmisi sosial pengetahuan yang datang dari orang lainn artinya pengaruh sosial dengan interaksi dengan orang-orang sekitar atau teman. ${ }^{3}$

Pandagan para ahli tentang pemahaman teori ini

1. Menurut Alred Binet ${ }^{4}$ potensi kognitif seseorang terlihat dari kemampuannya dalam menyelesaikan tugas yang menyangkut pemahaman dan penalaran. Ada beberapa aspek yang mempengaruhi yang pertama, konsentrasi kemampuan dalam memusatkan pikiran ke suatu masalah yang harus diselesaikan atau dipecahkan. Yang kedua, adaptasi kemampuan atau penyesuaian terhadap masalah yang dihadapi atau fleksibel dalam menghadapi masalah. Yang ketiga, bersikap Kristis yaitu kemampuan untuk mengadakan kritik, terhadap masalah yang dihadapi, atau pun dirinya sendiri.

2. Menurut Carl Witherington kognitif adalah kecerdasan pikiran yang digunakan dengan cepat dan tepat dalam mengatasi suatu situasi dalam memecahkan masalah".

Teori kognitif mempuyai 4 (empat) macam proses belajar adaptif yang membentuk siklus, keempat proses belajar itu adalah concrete experience (CE), reffective observasition (RO), abstrak conceptualization (AC), dan active experimentation. Mula-mula orang memperoleh pengalaman kongkret CE. Dari pengalaman itu orang melakukan pengalaman reflektif orang itu menemukan konsep abstrak AC. Dan selanjutnya orang melakukan eksperimen secara aktif AE. Dari pengalaman aktif ini, orang menemukan pengalaman konkret $\mathrm{CE}$ lagi sehingga orang itu masuk ke dalam siklus CE-RO-AC-AE. ${ }^{5}$

\section{Alasan pemilihan nas}

Alasan penggunaa nas Alkitab dari kejadian, dirasa dapat dilakukan pendekatan dengan teori Kognitif yang diberikan kepada mahasiswa. Dimana mahasiswa akan menenali kisah Yusuf terlebih dahulu, dan melihat kerusakan etika yang dilakukan oleh saudaranya Yusuf. Dan dari sana mahasiswa akan diarahkan kepada kebenaran dari firman Tuhan itu dan muncul sebuah komitmen dari dalam diri mahasiswa.

\footnotetext{
${ }^{1}$ Susan B. Bastable, Perawat Sebagai Pendidik Prinsip-Prinsip Pengajaran dan Pembelajaran (Jakarta: EGC, 2002), Hal. 42.

${ }^{2}$ Dr. Muhammad Fathurrohman, M.PD.I, Belajar dan Pembelajaran modern (Yogyakarta: Garudhawaca, 2017), Hal. 16.

${ }^{3}$ Fatimah Ibda, "perkembangan Kognitif: teori Jeans Piaget", Jurnal Intelektualita Vol. 3 No. 1, 2015, Hal 29.

${ }^{4}$ Drs.Ahmad Susanto, M.Pd., Perkembagan Anak usia Dini (Jakarta: kencana, 2012), Hal. 51.

${ }^{5}$ Dali S.Naga, “letak psikologi pada peta kognitif”, Jurnal Provitae. No 1, 2004, Hal. 44.
} 


\section{Hubungan antara nas tersebut}

Hubungan yang ingin ditekankan disini adalah, pendekatan melalui teori ini dan tahap yang akan dihadapi mahasiswa dalam menangkap dan memahami nas ini. Mahasiswa diajak untuk dapat berintraksi dalam belajar sehingga mendapat sumbersumber informasi baru dalam belajar, jika melihat dari kisah Yusuf sendiri terdapat tahap-tahap kehidupan yang dilaluinya mulai dari dibenci saudaranya, dijual sebgai budak, dipenjara, hingga diangkat Tuhan secara perlahan dalam Hidupnya hingga dia berhasil dan menjadi orang nomor 2 di Mesir. Disini dapat dilihat hubungan kognitif yang juga punya tahapan-tahapan dalam belajar yang jika ditinjau dari kisah Yusuf menpuyai unsur yang sama.

\section{Metode}

Metode penulisan makalah ini adalah analisis data kualitatif yaitu menjelaskan data-data yang dikumpulkan sesuai dengan teori-teori yang dirangkum dari hasil penelitian. ${ }^{6}$ Selanjutnya dengan menggunakan model pembelajaran kooperatif berbasis media sosial. ${ }^{7}$ Dengan menggunakan metode 5P (Belajar berarti berubah). ${ }^{8}$

Metode yang dilakukan adalah metode belajar 5P dengan langkah-langkah sebagai berikut.

1. Menentukan Nast yang menjadi bahan pembelajaran.

Contoh : Pengampunan yang tidak biasa, peserta tentu saja sudah mengetahui atau sudah sering mendengar kisah Yusuf yang terambil dari kejadian. Peserta akan di bawa untuk mengigat kembali cerita ini, dan pikirkan.

Bagaimana perasaan saudara Yusuf setelah menjual Yusuf?

2. Pembahasan : pengampunan yang tidak biasa

Mahasiswa akan membahas cerita yang disampaikan tadi di kelompok tujuannya agar informasi yang di dapat berbeda-beda. Ceritakanlah pengampunan yang tidak biasa yang dilakukan oleh Yusuf kepada saudaranya dalam kelompok, dan dan tuliskan untuk menunjukan pengampunan tersebut dikertas anda.

Apa yang mempengaruhi Yusuf sehingga Yusuf mampu mengampuni saudaranya? Diskusikan di kelompok dan bagikan pendapatnya.

3. Penerapan : mahasiswa akan memikirkan dan diajak untuk merasakan apa yang dirasaka oleh tokoh.

Kelompok berdiskusi, apa saja yang anda pikirkan jika anda mengalami situasi seperti yang Yusuf alami.

4. Perubahan : setelah mereka merenungkan perubahan apa yang mereka rasakan dan perubahan apa yang didapat dari hasil diskusi tadi.

Renungkanlah secara individu perubahan apa yang harus anda lakukan terhadap diri anda setelah anda belajar dari kisah Yusuf.

\footnotetext{
${ }^{6}$ Hengki Wijaya and Helaluddin Helaluddin, Analisis Data Kualitatif Sebuah Tinjauan Teori \& Praktik (Makassar: Sekolah Tinggi Theologia Jaffray Makassar, 2019).

${ }^{7}$ Hengki Wijaya and Arismunandar Arismunandar, "Pengembangan Model Pembelajaran Kooperatif Tipe STAD Berbasis Media Sosial,” Jurnal Jaffray 16, no. 2 (October 6, 2018): 175-96, https://doi.org/10.25278/jj71.v16i2.302.

${ }^{8}$ Roland Walker, "Learning That LASTS," n.d., https:/wycliffe.fi/wp-content/uploads/2018/12/intro-tolearning-that-lasts-walker.pdf.
} 
5. Penutupan : mahasiswa akan diajak untuk menulis perubahan yang mereka dapatkan dan membuat sebuah komitmen dari pelajaran yang didapat agar dapat diterapkan dalam kehidupan sehari-hari.

Buat komitmen tulis di stick noot yang sudah dibagikan dan berdoa agar roh kudus menyertai anda dalam memegang komitmen anda.

\section{Hasil dan pembahasan}

Dari metode belajar 5p Pengalaman yang di dapat dari belajar kelompok, dengan menganalisa masalah dalam keseharian. Dengan keaktifan mahasiswa dalam belajar dan mencari gaya belajarnya yang sesuai. Pembelajaran ini menekankan keaktifan dari mahasiswa dengan menerapkan kembali apa yang sudah di pelajari melaui pengalaman belajar. Hal ini pastinya melatih mahasiswa dalam berfikir dan mendapat pemecahan masalah melalui, fenomena, dan fakta yang mereka lihat dan mereka rasakan melaui proses belajar dan bahan ajar yang disampaikan. Aktivitas yang dilakukan dengan berkelompok mulai dari, kegiatan diskusi, mendengar, menuliskan. Dengan adanya partisipasi dari mahasiswa, dalam mengajukan pendapat atau ide serta gagasan yang terlintas dipikiran mahasiswa dalam menerima materi. Dapat dipastikan akan terbentuklah pengetahuan mahasiswa dalam memecahkan masalah.

\section{Kesimpulan}

Tujuan dari penulisan ini adalah untuk melihat pengaruh teori kognitif dalam proses belajar yang dilakukan oleh mahasiswa. Bagaimana mahasiswa menggunakan logika mereka dalam memecahkan masalah, dengan melibatkan tindakan dan aktifan dalam belajar sehingga menimbulkan perubahan prilaku yang terjadi karna proses belajar. Metode kognitif sendiri sangat penting diterapkan dalam pendidikan karna dengan proses belajar, dan proses berpikir mahasiswa dapat memecahkan masalah, dan matang dalam mengambil keputusan.

\section{Daftar Pustaka}

Bastable, Susan. Perawat sebagai pendidik Prinsip-Prinsip Pengajaran dan Pembelajaran. Jakarta: EGC, 2004.

Fathurrohman, Muhammad. Belajar dan pembelajaran modern. Yogyakarta: Garudhawacana, 2017.

Ibda, Fatimah. "Perkembangan Kognitif: Teori Jeans Pieget”, jurnal Inteletualita 3, No. $1,2012$.

Susanto, Ahmad. Perkembangan anak usia dini. Jakarta: kencana, 2012.

Naga, Dali. “Letak psikologi pada peta kognitif”. jurnal provitae, No.1, 2004.

Walker, Roland. "Learning That LASTS," n.d. https://wycliffe.fi/wpcontent/uploads/2018/12/intro-to-learning-that-lasts-walker.pdf. 
Wijaya, Hengki, and Arismunandar Arismunandar. "Pengembangan Model Pembelajaran Kooperatif Tipe STAD Berbasis Media Sosial." Jurnal Jaffray 16, no. 2 (October 6, 2018): 175-96. https://doi.org/10.25278/jj71.v16i2.302.

Wijaya, Hengki, and Helaluddin Helaluddin. Analisis Data Kualitatif Sebuah Tinjauan Teori \& Praktik. Makassar: Sekolah Tinggi Theologia Jaffray Makassar, 2019. 